\title{
Hematodinium sp. (Alveolata, Syndinea) detected in marine decapod crustaceans from waters of Denmark and Greenland
}

\author{
F. Eigemann ${ }^{1,4}{ }^{,}$, A. Burmeister ${ }^{2}$, A. Skovgaard ${ }^{3}$ \\ ${ }^{1}$ University of Copenhagen, Department of Biology, Øster Farimagsgade 2D, 1353 Copenhagen K, Denmark \\ ${ }^{2}$ Greenland Institute of Natural Resources, Postbox 576, 3900 Nuuk, Greenland \\ ${ }^{3}$ University of Copenhagen, Faculty of Life Sciences, Laboratory of Aquatic Pathobiology, Stigbøjlen 7, 1870 Frederiksberg, \\ Denmark \\ ${ }^{4}$ Present address: Leibniz-Institute of Freshwater Ecology and Inland Fisheries, Müggelseedamm 301, 12587 Berlin, \\ Germany
}

\begin{abstract}
Five decapod crustacean species were examined for presence of the parasitic dinoflagellate Hematodinium spp. (Alveolata, Syndinea) by morphological methods (colour and pleopod methods) as well as by PCR and nested PCR with Hematodinium-specific primers. Nephrops norvegicus, Pagurus bernhardus and Liocarcinus depurator were sampled by trawling in Danish waters and Chionoecetes opilio and Hyas araneus were sampled by trapping off the west coast of Greenland. The existence of Hematodinium has not previoiusly been documented in Danish waters, but it was detected in all 3 decapod species examined in the present study. Hematodinium sp. was also detected for the first time in $H$. araneus and the existence of Hematodinium sp. in Greenlandic C. opilio was documented by PCR. Analyses of 26 Hematodinium sp. ITS1 sequences, including sequences from all 5 host species sampled, revealed more than $95 \%$ sequence similarity between 24 of the sequences. Two Hematodinium sp. ITS1 sequences from C. opilio were only $81 \%$ similar to the 24 other ITS1 sequences. The nested PCR approach resulted in the highest reported percentages of positive samples for Hematodinium sp.in the hosts investigated (between 45 and $87.5 \%$ ). However, no decapods were found to be infected with Hematodinium sp. based on morphological methods. Consequently, Hematodinium sp. may be more common than previously believed, and, assuming that the DNA found originated from viable and infectious parasite cells, infections may not always be fatal. We suggest that the hosts investigated may have been subject to latent infections that could develop into a fatal disease only if the hosts were physiologically stressed due to other factors.
\end{abstract}

KEY WORDS: Hematodinium · Latent infections $\cdot$ ITS1 $\cdot$ Parasitic dinoflagellates $\cdot$ PCR detection

\section{INTRODUCTION}

Several crustacean decapods are parasitized by dinoflagellates of the genus Hematodinium (Stentiford \& Shields 2005). This genus was first described by Chatton \& Poisson (1931) with the type-species $H$. perezi infecting 2 different hosts, Carcinus maenas and Liocarcinus depurator, off the coast of France. Hematodinium spp. have since been recorded worldwide from a broad array of decapod hosts, including commercially and ecologically important species (Stentiford \& Shields 2005). Infection with Hematodinium sp. is often referred to as bitter crab disease (BCD, Meyers et al. 1987) or pink crab disease (PCD, Stentiford et al. 2002).

Morphological examinations of parasite cells (Meyers et al. 1987, Field et al. 1992, Stentiford \& Shields 2005) suggested the existence of several Hematodinium species and molecular and biochemical analyses have indicated that at least 2 groups of Hemato- 
dinium sequences may warrant species status (Small et al. 2007b,c, Jensen et al. 2010). Different Hematodinium genotypes were related to different host species (Small et al. 2007b, Hamilton et al. 2010, Jensen et al. 2010) and geographical regions (Hamilton et al. 2010). It is also clear, however, that a single Hematodinium genotype may infect more than one host species (Hamilton et al. 2007, 2010, Small et al. 2007a, Jensen et al. 2010). However, so far only one other species of Hematodinium has been formally described, namely $H$. australis, which was described on the basis of morphology, host species, and austral location (Hudson \& Shields 1994).

In some host species, advanced infections lead to a discoloration of the carapace from reddish-brown to a reddish 'cooked' appearance (e.g. in Nephrops norvegicus and Chionoecetes opilio) and this may be used for detection of the disease (colour method; Meyers et al. 1987, Field et al. 1992). Rapid logarithmic growth of parasitic cells in the host's haemolymph causes a colour change from bluish-transparent to milky-white (e.g. Shields \& Squyars 2000) and aggregation of parasitic cells occurs. In $N$. norvegicus and Callinectes sapidus, such aggregation can be seen when a pleopod is removed and observed under an inverted microscope (pleopod method, Field et al. 1992). Both morphological detection methods can only detect advanced infections and, therefore, underestimate parasite prevalence (Stentiford et al. 2001). For parasite detection, additional histological (Messick 1994, Messick \& Shields 2000), immunological (Stentiford et al. 2001, Small et al. 2002) and molecular methods (Hudson \& Adlard 1994, Gruebl et al. 2002, Small et al. 2006) are available that are also able to detect lowlevel (low parasite numbers in the host) infections. However, a staging of disease progression was only established for the pleopod method (Field et al. 1992, Field \& Appleton 1995), which fails to detect latent and sub-patent infections (Stentiford et al. 2001). Therefore, an evaluation of disease status from low-level latent infections to apparent, patent peak infections is not yet possible.

Severely infected crabs are moribund and probably die due to oxygen depletion, organ dysfunction or secondary infections (Meyers et al. 1987). Due to seasonal prevalence of up to $85 \%$ (e.g. Callinectes sapidus, Shields et al. 2003) in specific areas, Hematodinium spp. can have significant effects on host populations and economic losses for commercial crustacean fisheries are thought to be considerable (e.g. Field \& Appleton 1995, Wilhelm \& Miahle 1996). Epizootics in commercially exploited stocks are documented for Chionoecetes opilio (Taylor \& Khan 1995), Chionoecetes bairdi (Meyers et al. 1987), Callinectes sapidus (Newman \& Johnson 1975), Nephrops norvegicus
(Field et al. 1992), Cancer pagurus (Stentiford et al. 2002) and Necora puber (Wilhelm \& Boulo 1988).

In the present study, 5 different decapod host species were examined for the presence of Hematodinium spp. DNA by PCR and nested PCR. Furthermore, samples of Chionoecetes opilio and Nephrops norvegicus were examined by the colour method and samples of $N$. norvegicus were also examined by the pleopod method to compare morphological and molecular methods. Positive PCR products were sequenced and the Hematodinium sp. sequences obtained were compared and examined for regional and/or host-related differences.

\section{MATERIALS AND METHODS}

Samples of Chionoecetes opilio and Hyas araneus were collected during a cruise between June 4 and 20, 2007 , in the Sisimiut area off the west coast of Greenland (Fig. 1A). Crabs were caught by means of traps baited with cephalopods, with 10 traps in a line at each station. All samples of C. opilio (approximately 14 000) were examined by the colour method and 100 randomly selected crabs (5 stations with 20 crabs each) were also examined by nested PCR (Standard PCR, $\mathrm{n}=$ 40). Correlations between samples showing positive for Hematodinium sp. and sample stations of C. opilio were analysed with a chi-square test, and between percentages of Hematodinium sp.-positive samples and depth or water temperature by Spearman's $\rho$ test. Statistical analyses were performed using the software package SPSS.

Samples of Hyas araneus $(\mathrm{n}=20)$ were examined solely by nested PCR. Samples of Pagurus bernhardus ( $\mathrm{n}=10$ ) were collected by trawling in The Sound, Denmark, on April 16, 2007 (Fig. 1B). Nephrops norvegicus ( $\mathrm{n}=72$ ) and Liocarcinus depurator $(\mathrm{n}=8$ ) were caught by trawling on May 30, 2007, in the Kattegat, Denmark (Fig. 1B). All L. depurator and P. bernhardus samples were examined by nested PCR and $P$. bernhardus specimens additionally by standard PCR. Out of $72 \mathrm{~N}$. norvegicus samples, 52 were examined by standard PCR and 20 by nested PCR, and all N. norvegicus samples were also examined by the colour and pleopod methods. For the pleopod method, the 3rd pleopod on the right side (ventral, caudal view) was removed and examined under an inverted microscope for aggregation of parasite cells (Field et al. 1992). For PCR, $1 \mathrm{ml}$ of haemolymph and a piece of heart tissue (ca. $5 \mathrm{~mm}^{3}$ ) were removed from each crab, stored in $300 \mu \mathrm{l}$ of $2 \times 1 \% \mathrm{~N}$-cetyl N,N,N-trimethylammonium bromide $(\mathrm{CTAB})$ and frozen at $-20^{\circ} \mathrm{C}$ until further treatment.

Cell destruction was performed with a TissueLyser (Qiagen Retsch) using silica beads (haemolymph sam- 

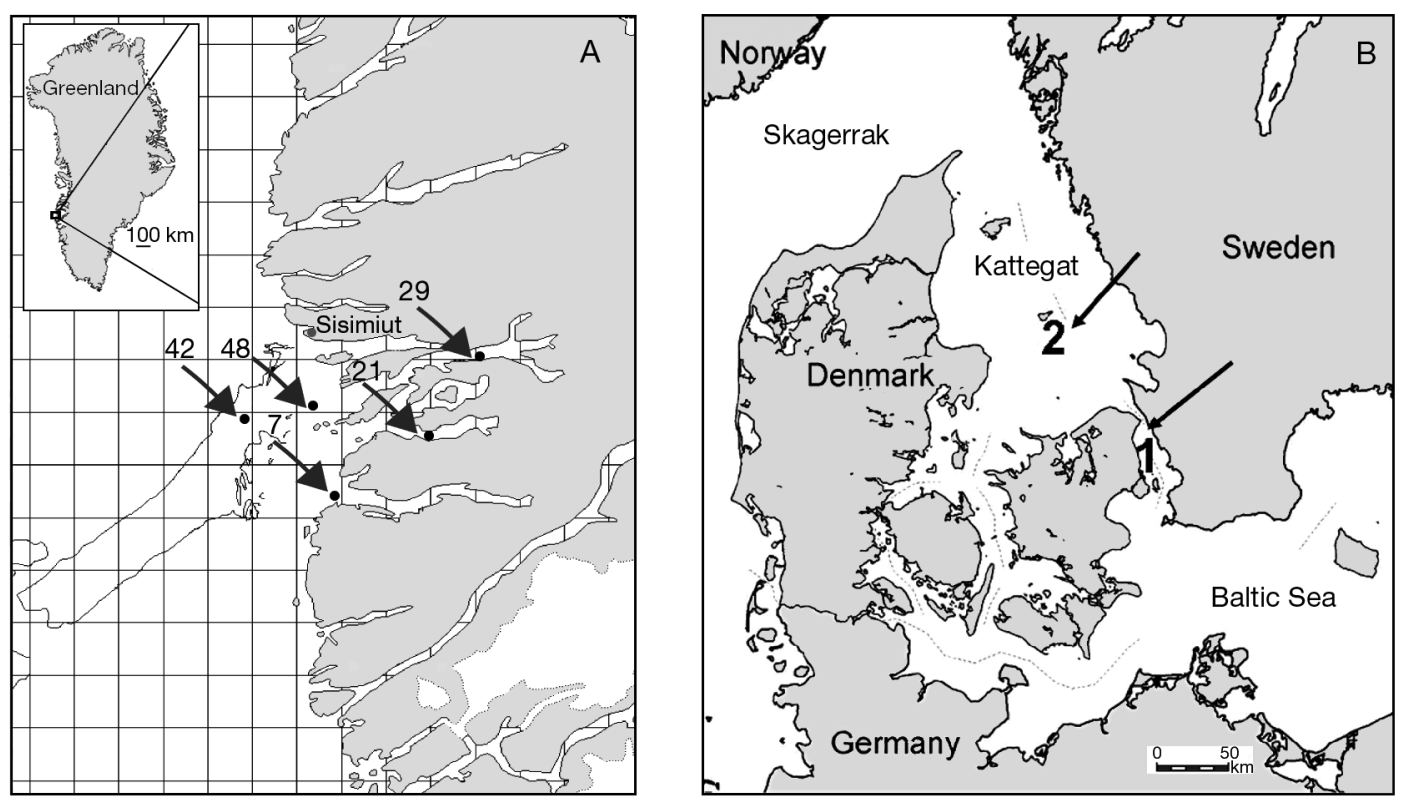

Fig. 1. Sampling sites to detect presence of Hematodinium. (A) Greenland: Chionoecetes opilio and Hyas araneus. (B) Denmark: Pagurus bernhardus (Stn 1), and Nephrops norvegicus and Liocarcinus depurator (Stn 2)

ples) or metal beads (heart tissue samples). DNA was extracted with the CTAB protocol (Doyle \& Doyle 1987) and finally resolved in $30 \mu \mathrm{l}$ TE-buffer $(10 \mathrm{mM}$ TrisHCl, 1 mM EDTA, MilliQ $\mathrm{H}_{2} \mathrm{O}$ ). For the PCR, the Hematodinium-specific primer pair 18SF2 and ITSR1 (Small et al. 2006) was used, which amplifies parts of the 18S rRNA gene and partial ITS1 (380 bp). The nested PCR was conducted using primers Hemat1487F (Gruebl et al. 2002) and 5'-CGC ATT TCG CTG CGT TCT TC R (Hudson \& Adlard 1994) in the first PCR ( 680 bp) and 18SF2 (Small et al. 2006) and Hem3R (5'TAA CCC GAG CCG AGG CAT TCA) in the second PCR (480 bp). The primer Hem3R was designed based on known Hematodinium sp. sequences from GenBank. It anneals to the 5' end of the 5.8S rRNA gene and, thereby, amplifies the entire ITS1 if used together with 18SF2. A search with the basic local alignment search tool (BLAST) showed that the Hem3R primer sequence only matched well with Hematodinium spp. sequences. The specificity of the primer was checked by performing a nested PCR on extract of the closest known relative of Hematodinium, Syndinium turbo. This reaction yielded no detectable product.

PCR reactions were performed using $2 \mu$ of template DNA (or autoclaved, distilled water as negative control), $5 \mu \mathrm{l}$ of each $10 \mu \mathrm{M}$ primer, $0.1 \mu \mathrm{l}$ Taq-polymerase (Ampliqon), $20 \mu \mathrm{l}$ of $0.5 \mathrm{mM}$ dNTP mix, $5 \mu \mathrm{l}$ buffer (TrisHCl, pH 8.5, $\mathrm{MgCl}_{2}, \mathrm{NH}_{4} \mathrm{SO}_{4}, 2$-mercaptoethanol), $5 \mu$ tetramethylammonium chloride $\left(\mathrm{C}_{4} \mathrm{H}_{12} \mathrm{NCl}\right)$ and $8 \mu \mathrm{l}$ autoclaved distilled water (total volume, $45.1 \mu \mathrm{l}$ ). PCR conditions were as follows: an initial denaturation step at $94^{\circ} \mathrm{C}$ for 1 min followed by 35 cycles of denaturation at $94^{\circ} \mathrm{C}$ for $1 \mathrm{~min}$, primer annealing at $58^{\circ} \mathrm{C}$ for $1 \mathrm{~min}$ and chain extension at $72^{\circ} \mathrm{C}$ for $2 \mathrm{~min}$. This was finalized with an extension step at $72^{\circ} \mathrm{C}$ for $6 \mathrm{~min}$. Nested PCR reactions were done as described above, but $0.2 \mu \mathrm{l}$ from the first PCR were used as template and the number of cycles was decreased to 30. Aliquots of $4 \mu \mathrm{l}$ from each PCR reaction were checked for amplification products using $1.5 \%(\mathrm{w} / \mathrm{v})$ ethidium bromide (EtBr)-stained agarose gels and a Kodak EDAS 290 apparatus for subsequent image analysis.

A crab was considered to be Hematodinium sp.-positive if either the PCR product of the haemolymph or the heart tissue sample, or both, showed a bright band of the appropriate length (standard PCR, $380 \mathrm{bp}$; nested PCR, $480 \mathrm{bp}$ ). Several amplification products from all examined hosts were purified using NucleoFast 96 PCR plates (Clontech-Takara Bio Europe) and bidirectionally sequenced by Macrogen (Korea), with the same primers as used for the PCR. All sequences were verified as being from Hematodinium sp. (BLAST searches) and then manually edited with BioEdit (Hall 1999). Sequence parts belonging to the $18 \mathrm{~S}$ and $5.8 \mathrm{~S}$ rRNA genes were removed after comparing with a sequence from the closest known relative of Hematodinium (Syndinium turbo, Skovgaard et al. 2005) and the remaining ITS1 sequences were compared pairwise using MEGA4 (Tamura et al. 2007). Sequence similarities were calculated as percentages of identical bases. Evolutionary distances between ITS1 sequences obtained in the present study and sequences taken 


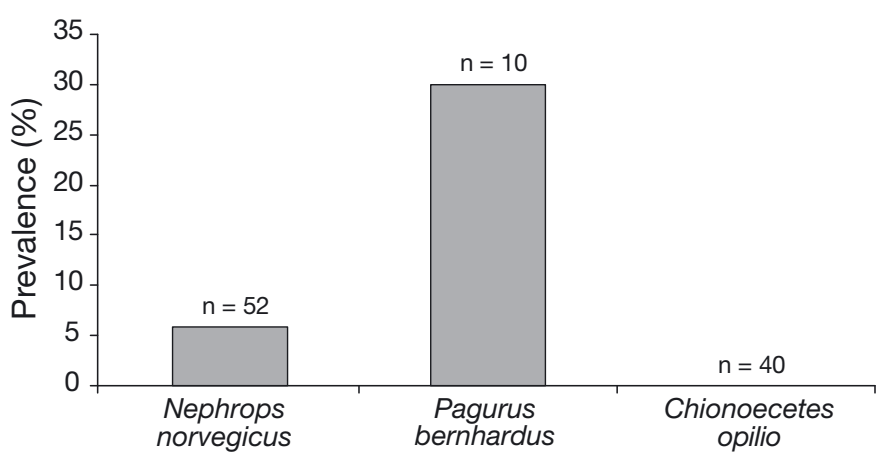

Fig. 2. Hematodinium spp. Percentages of Hematodiniumpositive samples detected by standard PCR using primers 18SF2 and ITSR1

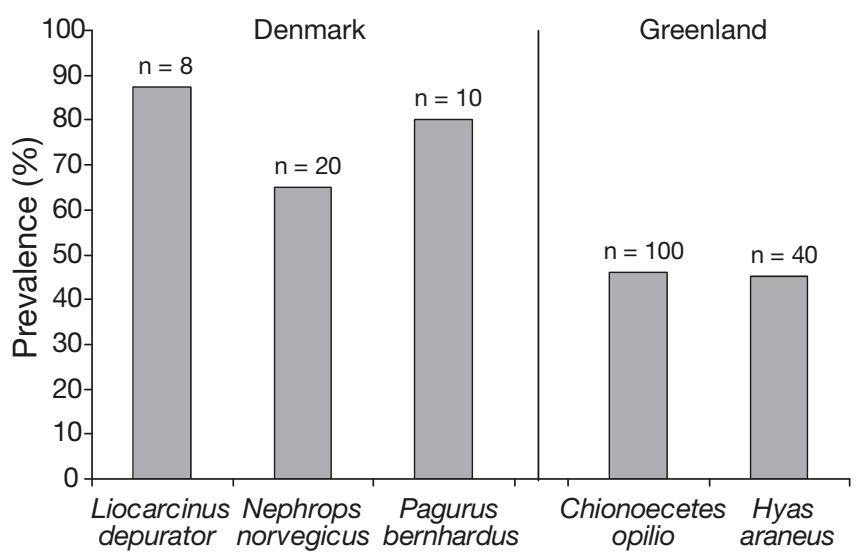

Fig. 3. Hematodinium spp. Percentages of Hematodiniumpositive samples detected by nested PCR for the 5 host species from GenBank (Clade B as defined by Jensen et al. 2010, and sequences from each subclade defined by Hamilton et al. 2010) were estimated with an alignment of 13 sequences (4 obtained in the present study and 9 taken from GenBank) using MEGA4 (Tamura et al. 2007), whereby positions containing gaps were eliminated from the data set. There were a total of 289 positions in the final alignment (excluding gap-containing positions). A pairwise alignment and comparison were made using BioEdit v. 7.0.9 in which positions containing gaps were included.

\section{RESULTS}

\section{Colour and pleopod method}

Based on the colour method, none of the collected Chionoecetes opilio ( $\mathrm{n}=14000$ ) and Nephrops norvegicus $(\mathrm{n}=72)$ revealed indications of Hematodinium sp. infection. Samples of $N$. norvegicus were also examined by the pleopod method without detecting any parasite cells in the haemolymph.

\section{PCR detection}

With the standard PCR approach, prevalence of Hematodinium sp.-positive samples was $0 \%$ for Chionoecetes opilio ( $\mathrm{n}=40), 30 \%$ for Pagurus bernhardus $(\mathrm{n}=10)$ and $5.8 \%$ for Nephrops norvegicus $(\mathrm{n}=52)$ (Fig. 2). A few samples, e.g. samples $2 \mathrm{~b}$ and $7 \mathrm{a}$ of $P$. bernhardus, produced weak double bands (see Fig. 4), which could not be accounted for. With the nested PCR
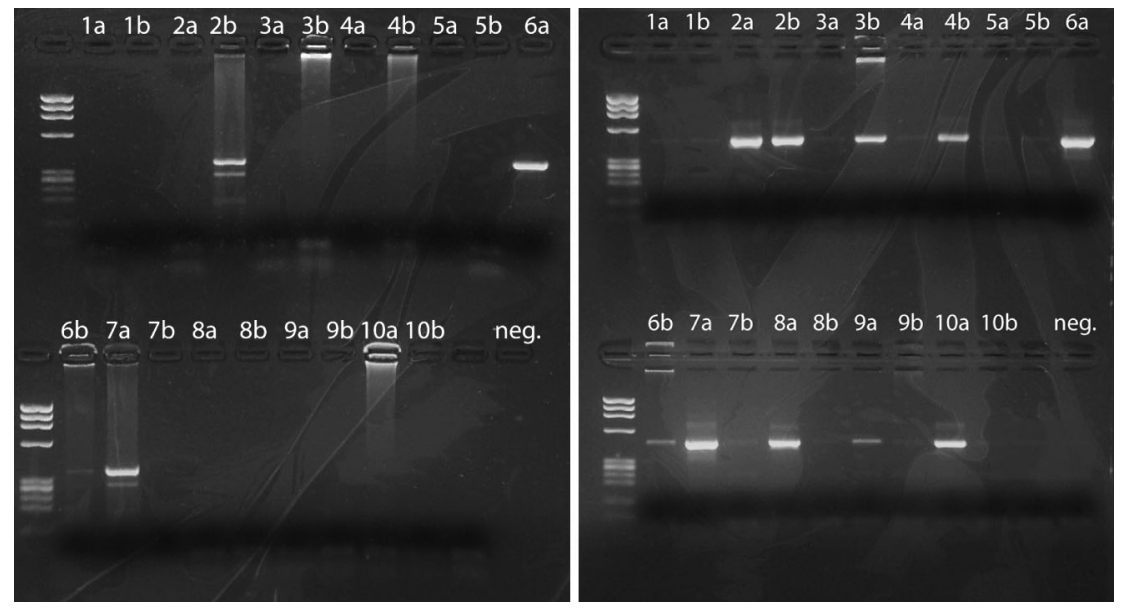

Fig. 4. Pagurus bernhardus. Comparison of standard PCR and nested PCR performed on the same 10 host individuals. The left gel shows the standard PCR and the right gel the nested PCR. Bands of molecular weight ladder represent 1353, 1078, 872, 603, 310, 281, 271, 234, 144 bp (from top to bottom). a: haemolymph sample; b: heart tissue sample; neg.: negative control 
approach, the prevalence of Hematodinium sp.-positive samples was estimated as follows: $87.5 \%$ for Liocarcinus depurator $(\mathrm{n}=8), 65 \%$ for $N$. norvegicus $(\mathrm{n}=$ 20), $46 \%$ for C. opilio ( $\mathrm{n}=100), 45 \%$ for Hyas araneus (n $=40)$ and $80 \%$ for $P$. bernhardus $(\mathrm{n}=10)$ (Figs. $3 \&$ 4). All $P$. bernhardus samples and 40 out of $100 C$. opilio samples were examined with both PCR approaches. Samples of $N$. norvegicus were also examined with both PCR approaches, but in this case standard PCR and nested PCR were done on samples from different host specimens.

\section{Distribution of Hematodinium sp.-positive samples in Chionoecetes opilio}

There was a significantly higher detection frequency of Hematodinium sp.-positive samples detected by nested PCR in specimens of Chionoecetes opilio collected at inshore sample stations in comparison with offshore samples (chi-square test, $\mathrm{p}=0.05$ ): percentages of Hematodinium sp.-positive hosts were 3 -fold higher at the inner stations (Fig. 1A, Table 1). The water depth at sampling stations ranged from 206 to $421 \mathrm{~m}$ and bottom temperature ranged from -1.0 to $2.3^{\circ} \mathrm{C}$. There were no apparent correlations between percentages of Hematodinium sp.-positive samples and either depth (Spearman's $\rho$ test: correlation coefficient $=0.4, \mathrm{p}=0.505, \mathrm{n}=5$ ) or water temperature (Spearman's $\rho$ test: correlation coefficient $=-0.6, \mathrm{p}=$ $0.285, \mathrm{n}=5$ ) (Table 1).

\section{Sequence similarities}

A total of 31 PCR products of the appropriate length (ca. 480 bp, partial 18S, complete ITS1, partial 5.8S) were sequenced to determine whether they represented Hematodinium sp.; 26 of these sequences were without ambiguous positions and were deposited in GenBank. Five of the 31 sequences revealed several doubtful base pairs and were eliminated from further analysis. Five different ITS1 sequences were found (Fig. 5). Accession numbers, host species and sample location for the sequences are listed in Table 2.

Twenty-four ITS1 sequences (Fig. 5, sequence numbers $1,3,4,5)$, including sequences from all 5 hosts, showed more than $95 \%$ similarity when compared pairwise. Two sequences from Chionoecetes

Table 1. Hematodinium sp. Sampling stations categorized as inner (i), edge (e) and offshore (o) stations with the respective depth and temperature. Prevalence of Hematodinium sp. is given as percentage of Hematodinium sp.-positive samples generated by nested PCR. All stations, $n=20$

\begin{tabular}{|lccc|}
\hline Station & $\begin{array}{c}\text { Hematodinium sp. } \\
\text { prevalence }(\%)\end{array}$ & $\begin{array}{c}\text { Temperature } \\
\left({ }^{\circ} \mathrm{C}\right)\end{array}$ & $\begin{array}{c}\text { Depth } \\
(\mathrm{m})\end{array}$ \\
\hline 21 (i) & 60 & -1.0 & 261.5 \\
$29(\mathrm{i})$ & 85 & 1.2 & 347.5 \\
$7(\mathrm{e})$ & 40 & -0.5 & 259 \\
$42(\mathrm{o})$ & 35 & 2.3 & 421 \\
$48(\mathrm{o})$ & 10 & 2.1 & 206 \\
\hline
\end{tabular}

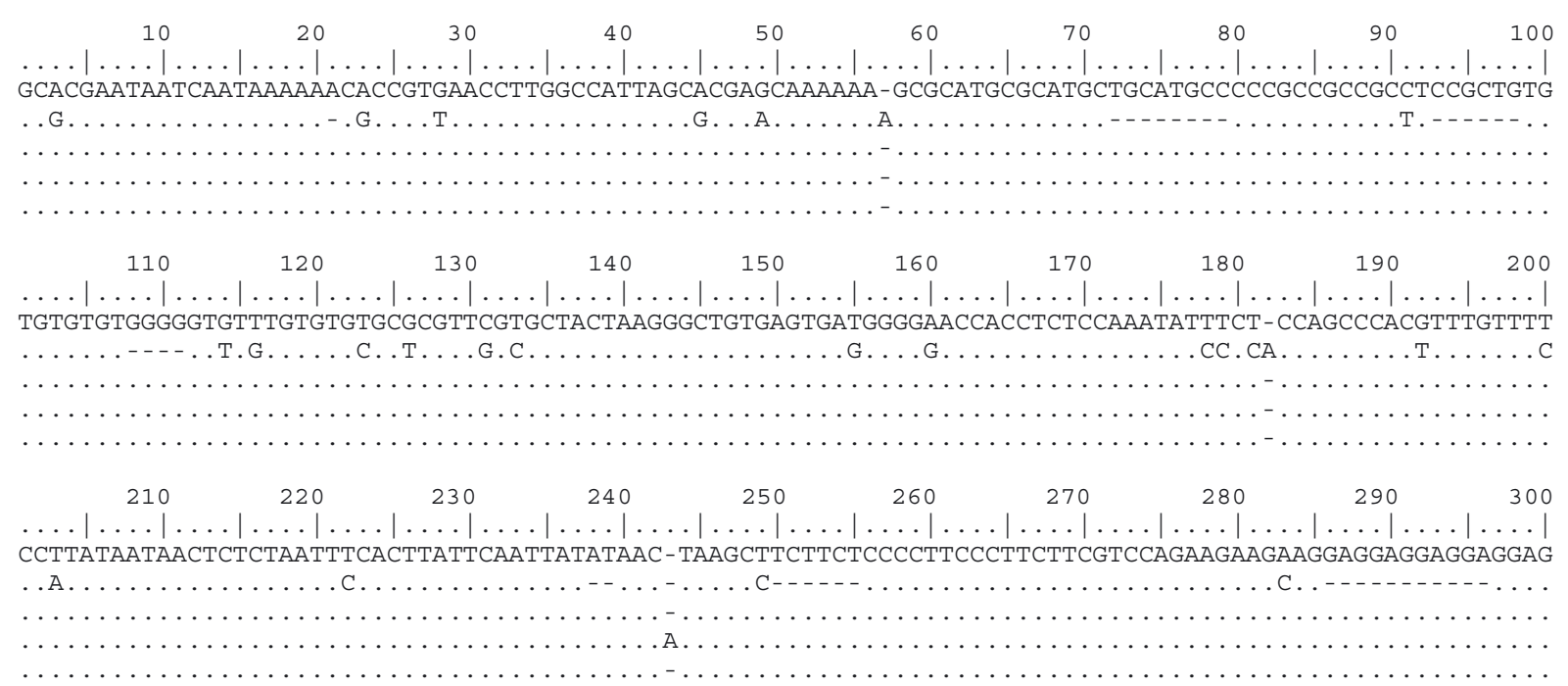

330

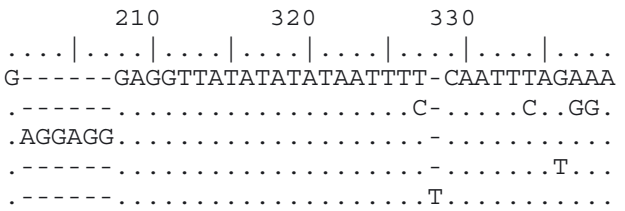

Fig. 5. Hematodinium spp. Alignment of the 5 different ITS1 sequences found (see Table 2); Sequence 1, hosts: Hyas araneus, Nephrops norvegicus, Chionoecetes opilio, Liocarcinus depurator, Pagurus bernhardus. Sequence 2 (outliers), host: C. opilio. Sequence 3, hosts: N. norvegicus, C. opilio. Sequence 4, host: C. opilio. Sequence 5, host: L. depurator. Dots (.): conserved nucleotides; dashes (-): gaps 
Table 2. Hematodinium sp. ITS1 sequences. Host species, accession number, number of identical sequences obtained (n) and sample locations for the 5 different sequences numbered 1 to 5 in Fig. 5. Seq. no. = sequence number

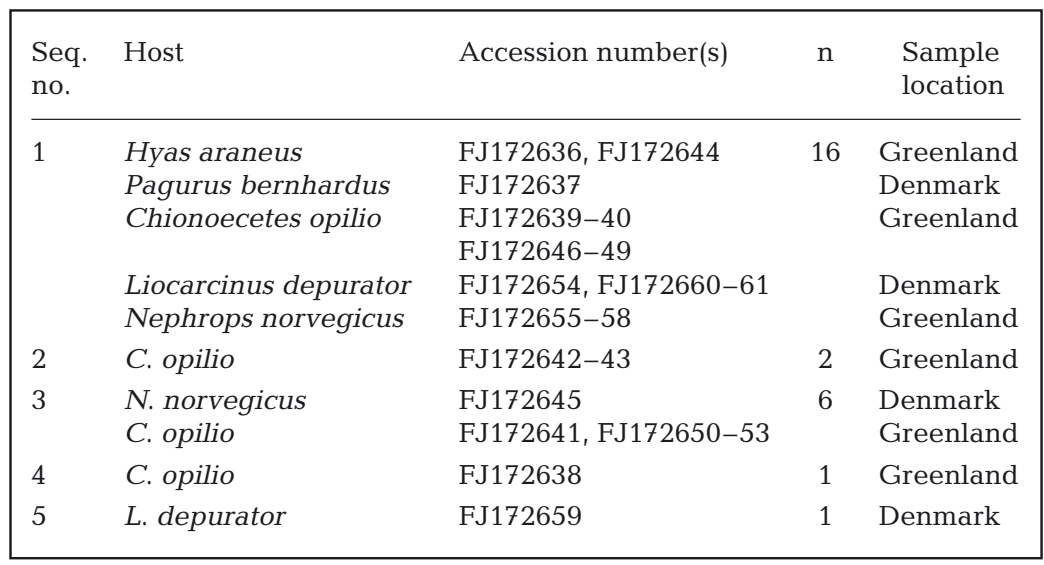

opilio (FJ172642 and FJ172643) only showed $81 \%$ similarity (Fig. 5, sequence number 2) to the other 24 sequences. These 2 sequences were more than $99 \%$ similar to each other. Six sequences (from the hosts Hyas araneus and $C$. opilio) showed an insertion of an AGG AGG at position 302-307 (Fig. 5, sequence number 3). A single sequence from C. opilio (Fig. 5, sequence number 4) exhibited a single A as insertion at position 243 and a $\mathrm{G}-\mathrm{T}$ substitution at position 336. Another sequence from Liocarcinus depurator (Fig. 5, sequence number 5) revealed an insertion of a $\mathrm{T}$ at position 328 . There was no obvious relationship between the type of Hematodinium sp. ITS1 sequence and host species or sampling area. The esti- mation of evolutionary distance of 13 Hematodinium sp.-ITS1 Clade B (sensu Jensen et al. 2010) sequences showed a close relation between the first 9 sequences ( $\geq 94 \%$ similarity, Table 3) comprising the hosts $L$. depurator, H. araneus, Pagurus bernhardus, Nephrops norvegicus, Carcinus maenas, Cancer pagurus and C. angulatus. Sequences 10 and 11 (hosts $P$. prideaux and Munida rugosa) showed similarities $\geq 89 \%$ to the first 9 sequences, whereas sequences 12 and 13 (host C. opilio) showed only 77 to $81 \%$ similarity to the first 9 sequences and 76 to $78 \%$ similarity to sequences 10 and 11 (Table 3).

\section{DISCUSSION}

\section{Morphological methods}

Many surveys have relied on the colour method (e.g. Meyers et al. 1990, Taylor \& Khan 1995) or the pleopod method (e.g. Field et al. 1992, Field \& Appleton 1995) to estimate the infection level of Hematodinium spp. in crustaceans. However, comparison between the colour method and haemolymph wet smears did reveal that the colour method underestimates the apparent infection level and only detects late stage infections (Meyers et al. 1990). The pleopod method can detect earlier stages of infections (Field et al. 1992) and a classifica-

Table 3. Hematodinium sp. Estimates of evolutionary divergence between Hematodinium sp. ITS1 sequences. Results are based on the pairwise analysis of 13 sequences. Lower left below diagonal: The number of base differences per sequence from analysis between sequences in an alignment of all 13 sequences conducted in MEGA4. Positions containing gaps were eliminated from the data set. There was a total of 289 positions in the final data set. Upper right above diagonal: Sequence identity; sequences were aligned and compared pairwise with BioEdit v. 7.0.9. Positions containing gaps were included in the data set

\begin{tabular}{|c|c|c|c|c|c|c|c|c|c|c|c|c|c|c|c|}
\hline $\begin{array}{l}\text { GenBank } \\
\text { no. }\end{array}$ & Host species & $\begin{array}{c}\text { Table } \\
\text { ID }\end{array}$ & $(1)$ & $(2)$ & (3) & $(4)$ & (5) & (6) & (7) & $(8)$ & (9) & $(10)$ & $(11)$ & $(12)$ & (13) \\
\hline FJ495187 & Pagurus bernhardus & (1) & & 1.00 & 0.95 & 0.95 & 0.97 & 0.97 & 0.98 & 0.94 & 0.96 & 0.92 & 0.90 & 0.78 & 0.78 \\
\hline EU096208 & Nephrops norvegicus & (2) & 0 & & 0.95 & 0.95 & 0.97 & 0.97 & 0.98 & 0.94 & 0.96 & 0.92 & 0.90 & 0.78 & 0.78 \\
\hline FJ172644 & Hyas araneus & (3) & 0 & 0 & & 1.00 & 0.98 & 0.98 & 0.95 & 0.99 & 0.96 & 0.97 & 0.94 & 0.81 & 0.81 \\
\hline FJ172660 & Liocarcinus depurator & (4) & 0 & 0 & 0 & & 0.98 & 0.98 & 0.95 & 0.99 & 0.96 & 0.97 & 0.94 & 0.81 & 0.81 \\
\hline EF675761 & Carcinus maenas & (5) & 0 & 0 & 0 & 0 & & 1.00 & 0.97 & 0.97 & 0.98 & 0.94 & 0.92 & 0.80 & 0.80 \\
\hline FJ844426 & Chionoecetes angulatus & 5 (6) & 0 & 0 & 0 & 0 & 0 & & 0.97 & 0.97 & 0.98 & 0.94 & 0.92 & 0.80 & 0.80 \\
\hline EF031974 & N. norvegicus & (7) & 0 & 0 & 0 & 0 & 0 & 0 & & 0.94 & 0.96 & 0.92 & 0.89 & 0.77 & 0.77 \\
\hline EF032012 & P. bernhardus & (8) & 1 & 1 & 1 & 1 & 1 & 1 & 1 & & 0.96 & 0.96 & 0.94 & 0.80 & 0.80 \\
\hline FJ495186 & Cancer pagurus & (9) & 5 & 5 & 5 & 5 & 5 & 5 & 5 & 6 & & 0.95 & 0.93 & 0.79 & 0.79 \\
\hline EU096218 & P. prideaux & $(10)$ & 11 & 11 & 11 & 11 & 11 & 11 & 11 & 12 & 8 & & 0.97 & 0.78 & 0.78 \\
\hline EU096217 & Munida rugosa & (11) & 19 & 19 & 19 & 19 & 19 & 19 & 19 & 18 & 14 & 8 & & 0.76 & 0.77 \\
\hline FJ172643 & Chionoecetes opilio & $(12)$ & 29 & 29 & 29 & 29 & 29 & 29 & 29 & 30 & 32 & 38 & 42 & & 0.99 \\
\hline FJ172642 & C. opilio & (13) & 29 & 29 & 29 & 29 & 29 & 29 & 29 & 30 & 32 & 38 & 42 & 0 & \\
\hline
\end{tabular}


tion system for the progress of the disease was established (Field et al. 1992, Field \& Appleton 1995). However, in the present study apparent Hematodinium sp. infections were not detected with any of the applied morphological methods, despite the fact that many Hematodinium sp.-positive samples were detected by running PCR on samples derived from the same host individuals. Probably no crabs were infected heavily enough for detection by any of the morphological methods. In fact, all crab specimens examined appeared healthy and it is unknown whether they would subsequently reveal symptoms of Hematodinium sp. infection.

\section{Prevalence of Hematodinium sp.}

This is the first report of Hematodinium in Danish waters. With nested PCR, Hematodinium was detected in all 3 decapods examined from Danish waters. However, the presence of Hematodinium in Denmark was expected because infected Nephrops norvegicus have been found in waters off the nearby Swedish west coast (Tärnlund 2000). The present study is also the first report of Hematodinium sp. in Hyas araneus, but the detection of Hematodinium sp. in $H$. araneus was likewise not surprising, considering that Hematodinium spp. infect a broad array of decapods (Stentiford \& Shields 2005). Furthermore, H. araneus and Chionoecetes opilio share habitats in Greenland, and Greenlandic C. opilio populations are already known to host Hematodinium sp. (A. Burmeister unpubl. data).

The 3-times higher prevalence of Hematodinium sp.positive Chionoecetes opilio at inner stations compared with offshore stations along the west coast of Greenland is consistent with previous studies showing that Hematodinium sp. is most abundant in closed coastal habitats (e.g. Shields 1994, Wilhelm \& Miahle 1996). Epizootics often occur in enclosed hydrological areas like fjords and poorly drained estuaries or other restricted areas (Shields 1994, Pestal et al. 2003, Shields et al. 2005). However, epizootics actually do occur in open areas (Meyers et al. 1996, Field et al. 1998, Briggs \& McAliskey 2002, Stentiford et al. 2002), but in open ocean systems, e.g. the habitats of $C$. opilio and $C$. bairdi in the Bering Sea, the prevalence of Hematodinium sp. is generally low and variable (Meyers et al. 1996). One reason might be that sheltered areas have a lower water exchange and closed host populations, but these possibilities are speculative as long as the complete life cycle of Hematodinium is not known.

The present study reveals the highest prevalence of Hematodinium sp. for the respective hosts to date.
Samples of Chionoecetes opilio ( $\mathrm{n}=40$, Stns 42 and 48), in which no Hematodinium sp. DNA could be detected using the primer set 18SF2/ITSR1 (Small et al. 2006, Fig. 2 present study), exhibited $22.5 \%$ Hematodinium sp.-positive samples with nested PCR (data not shown), and 10 Pagurus bernhardus specimens revealed $30 \%$ Hematodinium sp.-positive samples with standard PCR versus $80 \%$ with nested PCR (Figs. 2 to 4). Nephrops norvegicus samples were not examined with both protocols, but one catch from May 30, 2007, comprised 40 crabs from which 20 were examined by standard PCR (5\% Hematodinium sp.-positive) and the other 20 by nested PCR (65\% Hematodinium sp.positive), again indicating a higher detection sensitivity of the nested PCR. Unfortunately it was not possible to obtain samples from all host species in large numbers and in these cases prevalence of Hematodinium sp.-positive hosts can only be considered as estimates. However, data presented here suggest that Hematodinium sp. may be more common than previously believed, since high percentages of Hematodinium sp.-positive samples were observed in host populations that appeared to have low prevalence of Hematodinium sp. based on the lack of morphological symptoms of infection. It is likely that the actual percentage of Hematodinium sp.-positive samples was underestimated in the present study, due to the large amount of host DNA in the samples or the presence of undetected PCR inhibitors. The possible presence of such false negative samples was not addressed in detail. Juveniles of $N$. norvegicus and $C$. opilio typically show higher Hematodinium sp. prevalence than do adults (Field et al. 1992, Stentiford \& Shields 2005). In the present study, only adults were examined and, moreover, sampling was conducted during periods of the year when infection levels in the respective hosts are thought to be low (Field et al. 1992, 1998, Stentiford \& Shields 2005).

An infection with Hematodinim spp. is generally assumed to be fatal in many host species (e.g. Meyers et al. 1987, Stentiford \& Shields 2005). However, assuming that the Hematodinium sp. DNA detected in the present study stems from viable and infectious parasite cells, with 45 to $87.5 \%$ of all examined crustaceans potentially hosting Hematodinium, this is unlikely, because no population declines associated with Hematodinium epizootics have been reported for the examined stocks (A. Burmeister unpubl. data). We hypothesise that hosts may be experiencing latent infections that will only lead to symptoms if the host is stressed or otherwise experiencing unfavourable conditions. For detection of latent infections several assays have been developed (Field \& Appleton 1996, Stentiford et al. 2001). However, in these studies the term latent infections refers to low parasite numbers in the 
host (i.e. infections cannot be diagnosed with the colour or pleopod methods), and it is assumed that all latent infections will develop into apparent infections. Widespread latent infections that do not necessarily develop into apparent infections are known from other alveolate parasites, such as Toxoplasma gondii (Jakubek et al. 2007), and represent a common phenomenon in the biology of parasites. Stentiford et al. (2002) reported that in 2000 to 2001 most Cancer pagurus individuals died during transportation from their fishing grounds in the UK to other European countries. All of these crabs were infected with Hematodinium sp. and the disease may have become fatal due to the stress associated with capture, handling and transportation. Also Hematodinium sp.-infected Callinectes sapidus crabs died if stressed by handling or capture (Shields et al. 2003). However, stock declines cannot be explained solely by stress on the crustaceans, but future research may benefit from taking into account the combined effects of Hematodinium sp. infections and other biological and abiotic factors in the decline of decapod populations.

\section{Sequence comparison and evolutionary divergence}

Comparisons of ITS1 sequences indicated that all 5 hosts investigated harboured DNA from the same phylogroup of Hematodinium. This suggestion was corroborated by the estimation of evolutionary divergence between the sequences (Table 3). However, conclusions regarding species status or phylogeny should not be drawn as long as ITS1 sequences are the only data available (Burreson et al. 2005, Logares et al. 2007). In our analysis, sequences from Liocarcinus depurator were identical to sequences derived from Pagurus bernhardus, Chionoecetes opilio and Nephrops norvegicus. This finding was surprising since a previous study (Small et al. 2007c) found Hematodinium sp. ITS1 sequences derived from $L$. depurator to be only $\sim 50 \%$ similar to sequences derived from $P$. bernhardus, C. opilio and N. norvegicus (Clade B, Jensen et al. 2010). Hematodinium sp. ITS1 sequences from $L$. depurator were, on the other hand, very similar to sequences from Callinectes sapidus (i.e. Clade A, Jensen et al. 2010). In other words, representatives from both Hematodinium clades may be able to infect L. depurator. The present study is the first report that different Hematodinium phylogroups (Clades A and B) can be found in a single host species. Hamilton et al. (2010) suggested a host and geographically related distribution of Clade B Hematodinium sp. ITS1 sequences and generated a phylogenetic tree consisting of 3 subclades: NE Atlantic langustines ( $N$. norvegicus), NE Atlantic crabs (Carcinus maenas and Cancer pagurus), and an all NE and NW Atlantic host species subclade. However, this grouping may not be universal considering that the sequence FJ495187 from the crab $P$. bernhardus is identical to sequences from the NE Atlantic langustines subclade (e.g. EU096208, Table 3). Furthermore, Jensen et al. (2010) found a sequence FJ844426 from C. angulatus from the NW Atlantic that is identical to sequences from the NE Atlantic subclade (e.g. EF675761, Table 3).

Similarities between ITS1 sequences suggest that 2 outlier sequences, FJ172642 and FJ172643, (Fig. 5, sequence number 2, and Table 3 ) derived from Chionoecetes opilio are affiliated with Clade B (Jensen et al. 2010). It is noteworthy that these 2 sequences were very similar even though they originated from 2 different host crustaceans, and it is, therefore, unlikely that these 2 aberrant sequences were results of methodological artefacts. Comparison of the last $103 \mathrm{bp}$ of the 18S rRNA genes (adjacent to ITS1) reveals 99\% similarity between members of Clades A and B (Fig. 6). On the other hand, the 2 outlier sequences (FJ172642 and FJ172643) showed only 93\% similarity to $18 \mathrm{~S}$

\begin{tabular}{|c|c|c|c|c|c|c|}
\hline & & 0 & 20 & 30 & 40 & 0 \\
\hline FJ172655 & (Clade B) & CAGTTTCTGG & AAGTGGCAGC & TGGAAGTTTA & GTGAACCTTA & TCACTTAGAG \\
\hline EF153727 & (Clade A) & $\ldots \ldots \ldots$ & $\ldots \subset \ldots \ldots$ & $\ldots \ldots \ldots$ & $\ldots$ & $\ldots \ldots \ldots$ \\
\hline FJ172642 & (Outlier) & $\ldots \ldots \ldots$ & $\ldots \ldots \ldots$ & $\ldots$. G. . &.$c \ldots \ldots$ & $c \ldots \ldots$ \\
\hline & & 50 & 70 & 80 & 90 & 100 \\
\hline FJ172655 & (Clade B) & GAAGGAGAAG T & TCGTAACAAG & GTTTCCGTAG G & GTGAACCTGC G & GGAAGGATCA \\
\hline EF153727 & (Clade A) & & . & & & \\
\hline FJ172642 & (Outlier) & $\ldots$. $\ldots$ & $\cdots \cdots$ &.$c \ldots \ldots$. & $\ldots$ G.A... & $\cdots \ldots \ldots$ \\
\hline
\end{tabular}

Fig. 6. Hematodinium spp. Alignment of partial 18S rDNA sequences from Clades A and B (defined by Jensen et al. 2010) and the outlier sequence identified in the present study. Numbers in the left column are GenBank accession numbers 
sequences of Clades $\mathrm{A}$ and $\mathrm{B}$. It would have been desirable to obtain complete $18 \mathrm{~S}$ sequences of these 2 outlier sequences before making a final conclusion on their relationship, but attempts to generate such sequences were unsuccessful. ITS1 is a region that is usually more variable than the 18S rRNA gene (Jorgensen \& Cluster 1988). Thus, based on the partial $18 \mathrm{~S}$ sequences of FJ172642 and FJ172643, it is likely that they belong to a unrecognised species.

Acknowledgements. We thank the crew onboard RV 'Adolf Jensen' and RV 'Ophelia'. This work was supported by the Carlsberg Foundation (grant no. $04-0134 / 20$ to A.S.) and by The Danish Botanical Society.

\section{LITERATURE CITED}

Briggs RP, McAliskey M (2002) The prevalence of Hematodinium in Nephrops norvegicus from the Western Irish Sea. J Mar Biol Assoc UK 82:427-433

Burreson EM, Reece K, Dungan CF (2005) Molecular, morphological and experimental evidence support the synonymy of Perkinsus chesapeaki and Perkinsus andrewski. J Eukaryot Microbiol 52:258-270

Chatton E, Poisson R (1931) Sur l'existence, dans le sang des Crabes, de Peridinien parasites: Hematodinium perezi (Syndinidae). C R Seances Soc Biol Paris 105:553-557

Doyle JJ, Doyle JL (1987) A rapid DNA isolation procedure for small quantities of fresh leaf tissue. Phytochem Bull 19: $11-15$

Field RH, Appleton PL (1995) A Hematodinium-like dinoflagellate infection of the Norway lobster Nephrops norvegicus: observations on pathology and progression of infection. Dis Aquat Org 22:115-128

> Field RH, Appleton PL (1996) An indirect fluorescent antibody technique for the diagnosis of Hematodinium sp. infection of the Norway lobster Nephrops norvegicus. Dis Aquat Org 24:199-204

Field RH, Chapman CJ, Taylor AC, Neil DM, Vickerman K (1992) Infection of the Norway lobster Nephrops norvegicus by a Hematodinium-like species of dinoflagellates on the West Coast of Scotland. Dis Aquat Org 13:1-15

Field RH, Hills JM, Atkinson RJA, Magill S, Shanks AM (1998) Distribution and seasonal prevalence of Hematodinium sp. infection of the Norway lobster (Nephrops norvegicus) around the west coast of Scotland. ICES J Mar Sci 55:846-858

Gruebl T, Frischer ME, Sheppard M, Neumann M, Maurer AN, Lee RF (2002) Development of an 18S rRNA genetargeted PCR-based diagnostic for the blue crab parasite Hematodinium sp. Dis Aquat Org 49:61-70

Hall TA (1999) Bioedit: a user-friendly sequence alignment editor and analysis program for Windows 95/98/NT. Nucleic Acids Symp Ser 41:95-98

Hamilton KM, Morritt D, Shaw PW (2007) Molecular and histological identification of the crustacean parasite Hematodinium sp. (Alveolata, Syndinea) in the shore crab Carcinus maenas. Acta Protozool 46:183-192

> Hamilton KM, Morritt D, Shaw PW (2010) Genetic diversity of the crustacean parasite Hematodinium (Alveolata, Syndinea). Eur J Protistol 46:17-28

> Hudson DA, Adlard RD (1994) PCR techniques applied to Hematodinium spp. and Hematodinium-like dinoflagel- lates in decapod crustaceans. Dis Aquat Org 20:203-206

Hudson DA, Shields JD (1994) Hematodinium australis n. sp., a parasitic dinoflagellate of the sand crab Portunus pelagicus from Moreton Bay, Australia. Dis Aquat Org 19: $109-119$

Jakubek EB, Farkas R, Pálfi V, Mattsson JG (2007) Prevalence of antibodies against Toxoplasma gondii and Neospora caninum in Hungarian red foxes (Vulpes vulpes). Vet Parasitol 144:39-44

Jensen PC, Califf K, Lowe V, Hauser L, Morado JF (2010) Molecular detection of Hematodinium sp. in Northeast Pacific Chionoecetes spp. and evidence of two species in the Northern Hemisphere. Dis Aquat Org 89:155-166

Jorgensen RA, Cluster PD (1988) Modes and tempos in the evolution of nuclear ribosomal DNA: new characters for evolutionary studies and new markers for genetic and population studies. Ann Mo Bot Gard 75:1238-1247

> Logares R, Rengefors K, Kremp A, Shalchian-Tabrizi K and others (2007) Phenotypically different microalgal morphospecies with identical ribosomal DNA: a case of rapid adaptive evolution? Microb Ecol 53:549-561

Messick GA (1994) Hematodinium perezi infections in adult and juvenile blue crabs Callinectes sapidus from coastal bays of Maryland and Virginia, USA. Dis Aquat Org 19: $77-82$

Messick GA, Shields JD (2000) Epizootiology of the parasitic dinoflagellate Hematodinium sp. in the American blue crab Callinectes sapidus. Dis Aquat Org 43:139-152

- Meyers TR, Koeneman TM, Botelho C, Short S (1987) Bitter crab disease: a fatal dinoflagellate infection and marketing problem for Alaskan Tanner crab Chionoecetes bairdi. Dis Aquat Org 3:195-216

- Meyers TR, Botelho C, Koeneman TM, Short S, Imamura K (1990) Distribution of bitter crab dinoflagellate syndrome in southeast Alaskan Tanner crabs Chionoecetes bairdi. Dis Aquat Org 9:37-43

> Meyers TR, Morado JF, Sparks AK, Bishop GH, Pearson T, Urban D, Jackson D (1996) Distribution of bitter crab syndrome in Tanner crabs (Chionoecetes bairdi, C. opilio) from the Gulf of Alaska and Bering Sea. Dis Aquat Org 26: $221-227$

Newman MW, Johnson CA (1975) Disease of blue crabs (Callinectes sapidus) caused by a parasitic dinoflagellate, Hematodinium sp. J Parasitol 61:554-557

Pestal GP, Taylor DM, Hoenig JM, Shields JD, Pickavance R (2003) Monitoring the prevalence of the parasitic dinoflagellate Hematodinium sp. in snow crabs Chionoecetes opilio from Conception Bay, Newfoundland. Dis Aquat Org 53:67-75

Shields JD (1994) The parasitic dinoflagellates of marine crustaceans. Annu Rev Fish Dis 4:241-271

Shields JD, Squyars CM (2000) Mortality and hematology of blue crabs, Callinectes sapidus, experimentally infected with the parasitic dinoflagellate Hematodinium perezi. Fish Bull 98:139-152

Shields JD, Scanlon C, Volety A (2003) Aspects of the pathophysiology of blue crabs, Callinectes sapidus, infected with the parasitic dinoflagellate Hematodinium perezi. Bull Mar Sci 72:519-535

Shields JD, Taylor DM, Sutton SG, O'Keefe PG, Ings DW, Pardy AL (2005) Epidemiology of bitter crab disease (Hematodinium sp.) in snow crabs Chionoecetes opilio from Newfoundland, Canada. Dis Aquat Org 64:253-264

> Skovgaard A, Massana R, Balagué V, Saiz E (2005) Phylogenetic position of the copepod-infesting parasite Syndinium turbo (Dinoflagellata, Syndinea). Protist 156: $413-423$ 
Small HJ, Wilson S, Neil DM, Hagan P, Coombs GH (2002) Detection of the parasitic dinoflagellate Hematodinium in the Norway lobster Nephrops norvegicus by ELISA. Dis Aquat Org 52:175-177

Small HJ, Neil DM, Taylor AC, Atkinson RJA, Coombs GH (2006) Molecular detection of Hematodinium spp. in Norway lobster Nephrops norvegicus and other crustaceans. Dis Aquat Org 69:185-195

Small HJ, Shields JD, Moss JA, Reece KS (2007a) Conservation in the first internal transcribed spacer region (ITS1) in Hematodinium species infecting crustacean hosts found in the UK and Newfoundland. Dis Aquat Org 75:251-258

Small HJ, Shields JD, Neil DM, Taylor AC, Coombs GH (2007b) Differences in enzyme activities between two species of Hematodinium, parasitic dinoflagellates of crustaceans. J Invertebr Pathol 94:175-183

Small HJ, Shields JD, Hudson KL, Reece KS (2007c) Molecular detection of Hematodinium sp. infecting the blue crab, Callinectes sapidus. J Shellfish Res 26:131-139

Stentiford GD, Shields JD (2005) A review of the parasitic dinoflagellates Hematodinium species and Hematodinium-like infections in marine crustaceans. Dis Aquat Org 66:47-70

Stentiford GD, Neil DM, Coombs GH (2001) Development and application of an immunoassay diagnostic technique

Editorial responsibility: Rebecca Gast, Woods Hole, Massachusetts, USA for studying Hematodinium infections in Nephrops norvegicus populations. Dis Aquat Org 46:223-229

Stentiford GD, Green M, Bateman K, Small HJ, Neil DM, Feist SW (2002) Infection by a Hematodinium-like parasitic dinoflagellate causes Pink Crab Disease (PCD) in the edible crab Cancer pagurus. J Invertebr Pathol 79: 179-191

Tamura K, Dudley J, Nei M, Kumar S (2007) MEGA4: Molecular Evolutionary Genetics Analysis (MEGA) software version 4.0. Mol Biol Evol 24:1596-1599

Tärnlund S (2000) A comparison of two methods for identifying and assessing the parasitic dinoflagellate Hematodinium sp. in Norway lobster (Nephrops norvegicus). MS thesis, University of Göteborg

Taylor DM, Khan RA (1995) Observations on the occurrence of Hematodinium sp. (Dinoflagellata: Syndinidae), in the causative agent of Bitter Crab Disease in Newfoundland snow crab (Chionoecetes opilio). J Invertebr Pathol 65: 283-288

Wilhelm G, Boulo V (1988) Infection de l'etrille Liocarcinus puber (L.) par un dinoflagelle parasite de type Hematodinium sp. ICES CM 1988/K:41

> Wilhelm G, Miahle E (1996) Dinoflagellate infection associated with the decline of Necora puber crab populations in France. Dis Aquat Org 26:213-219

Submitted: December 18, 2008; Accepted: June 16, 2010 Proofs received from author(s): September 13, 2010 